OPEN ACCESS

Edited by:

George Tsiamis,

University of Patras, Greece

Reviewed by:

Zhongming $\mathrm{Ge}$,

Massachusetts Institute of Technology, United States

Óscar López,

Seville University, Spain

*Correspondence:

Claudiu T. Supuran

claudiu.supuran@unifi.it

Clemente Capasso

clemente.capasso@ibbr.cnr.it

${ }^{\dagger}$ These authors have contributed equally to this work

Specialty section:

This article was submitted to

Systems Microbiology,

a section of the journal

Frontiers in Microbiology

Received: 13 November 2020

Accepted: 22 February 2021

Published: 19 March 2021

Citation:

Campestre C, De Luca V, Carradori S, Grande R, Carginale V,

Scaloni A, Supuran CT and

Capasso C (2021) Carbonic

Anhydrases: New Perspectives on Protein Functional Role and Inhibition

in Helicobacter pylori.

Front. Microbiol. 12:629163. doi: 10.3389/fmicb.2021.629163

\section{Carbonic Anhydrases: New Perspectives on Protein Functional Role and Inhibition in Helicobacter pylori}

\author{
Cristina Campestre ${ }^{1 \dagger}$, Viviana De Luca ${ }^{2,3+}$, Simone Carradori ${ }^{1}$, Rossella Grande ${ }^{1}$, \\ Vincenzo Carginale ${ }^{2}$, Andrea Scaloni ${ }^{3}$, Claudiu T. Supuran ${ }^{4 *}$ and Clemente Capasso ${ }^{2 *}$ \\ 'Department of Pharmacy, "G. d'Annunzio" University of Chieti-Pescara, Chieti, Italy, ${ }^{2}$ Department of Biology, Agriculture \\ and Food Sciences, National Research Council (CNR), Institute of Biosciences and Bioresources, Naples, Italy, ${ }^{3}$ Proteomics \\ and Mass Spectrometry Laboratory, Institute for the Animal Production System in the Mediterranean Environment, National \\ Research Council (ISPAAM-CNR), Naples, Italy, ${ }^{4}$ Section of Pharmaceutical and Nutraceutical Sciences, Polo Scientifico, \\ Department of NEUROFARBA, University of Florence, Sesto Fiorentino, Italy
}

Our understanding of the function of bacterial carbonic anhydrases (CAs, EC 4.2.1.1) has increased significantly in the last years. CAs are metalloenzymes able to modulate $\mathrm{CO}_{2}, \mathrm{HCO}_{3}{ }^{-}$and $\mathrm{H}^{+}$concentration through their crucial role in catalysis of reversible $\mathrm{CO}_{2}$ hydration $\left(\mathrm{CO}_{2}+\mathrm{H}_{2} \mathrm{O} \rightleftarrows \mathrm{HCO}_{3}^{-}+\mathrm{H}^{+}\right)$. In all living organisms, CA activity is linked to physiological processes, such as those related to the transport and supply of $\mathrm{CO}_{2}$ or $\mathrm{HCO}_{3}{ }^{-}$, $\mathrm{pH}$ homeostasis, secretion of electrolytes, biosynthetic processes and photosynthesis. These important processes cannot be ensured by the very low rate of the non-catalyzed reaction of $\mathrm{CO}_{2}$ hydration. It has been recently shown that CAs are important biomolecules for many bacteria involved in human infections, such as Vibrio cholerae, Brucella suis, Salmonella enterica, Pseudomonas aeruginosa, and Helicobacter pylori. In these species, CA activity promotes microorganism growth and adaptation in the host, or modulates bacterial toxin production and virulence. In this review, recent literature in this research field and some of the above-mentioned issues are discussed, namely: (i) the implication of CAs from bacterial pathogens in determining the microorganism growth and virulence; (ii) the druggability of these enzymes using classical CA inhibitors (CAls) of the sulfonamide-type as examples; (iii) the role played by Helicobacter pylori CAs in the acid tolerance/adaptation of the microbe within the human abdomen; (iv) the role of CAs played in the outer membrane vesicles spawned by H. pylori in its planktonic and biofilm phenotypes; $(v)$ the possibility of using H. pylori CAls in combination with probiotic strains as a novel anti-ulcer treatment approach. The latter approach may represent an innovative and successful strategy to fight gastric infections in the era of increasing resistance of pathogenic bacteria to classical antibiotics.

Keywords: carbonic anhydrase, sulfonamide inhibitors, antibacterials, Helicobacter pylori, pathogens, membrane vesicles, biofilm, microbiota 


\section{INTRODUCTION}

\section{The Phenomenon of Antibiotic Resistance}

Bacteria are unicellular organisms having a simple circular DNA as genetic material, which ensures organism reproduction (Wang and Levin, 2009). Bacterial DNA is subjected to mutations or can acquire exogenous genes from other bacteria (Watford and Warrington, 2020). In the latter context, horizontal gene transfer is generally accomplished through the transfer of a plasmid, i.e., a small circular double-stranded extrachromosomal DNA containing one or more genes, or by the fusion of extracellular membrane vesicles (MVs), which are bilayer structures produced in a budding manner by other bacteria (Grull et al., 2018; Watford and Warrington, 2020). DNA mutations, gene transfer processes as well as other mechanisms, such as changes in the outer membrane permeability, drug extrusion by efflux pumps and modification of the drug target, can induce the bacteria to develop antibiotic resistance, which is now a severe global health problem (Annunziato, 2019; Carradori et al., 2020; Watford and Warrington, 2020). Different contexts determine antibiotic resistance, namely the abuse and over-prescription of drugs recommended to treat human infections, the frequent use of such drugs in livestock farming, and the consumption of vegetables, which may be contaminated with antibioticresistant bacteria coming from the manure used to fertilize vegetable farming (Ahl and Buntain, 1997; Roe and Pillai, 2003; Doyle, 2015). Infections caused by resistant bacteria are treated by administering other antibiotics to which they may still be sensitive (Fernando et al., 2017). However, bacteria may acquire resistance to such new classes of antibiotics, becoming multi-resistant organisms; accordingly, it is necessary to discover novel types of antibiotics, which can overcome the pan-resistance in these microorganisms (Walsh, 2005; Collignon, 2015; Molchanova et al., 2017). Nowadays, panresistant infections have become an odd reality, and clinicians face this increasing problem with treating multidrug-resistant strains of many pathogens (Walsh, 2005; Molchanova et al., 2017). In Europe, it has been estimated that the resistance to first-line of antibiotics (those of first use for the treatment of infections) will remain substantially stable in 2030 compared to 2005 levels. On the other hand, resistance to second-line antibiotics used when the first-line antibiotics are ineffective, such as the third generation cephalosporins and fluoroquinolones, is expected to increase by $75 \%$ in the same period (Rossi and Sternon, 2001). For third-line antibiotics (those of the last resort, such as polymyxins), resistance is expected to double compared to 2005 levels (Hartel et al., 2016). Therefore, the super-bacteria tsunami slowly but surely is hitting, and an effective strategy is needed to counteract it. A fundamental approach is to invest in developing new drugs, and replacing those that have lost effectiveness in the therapeutic settings (Dahle and Petersen, 2013; Littman and Halil, 2016; Cheesman et al., 2017). However, the research and development of novel medicines take many years, in some cases even more than a dozen per molecule in the early stages of development, before a new product can reach the market (Littman and Halil, 2016). Consequently, it is essential to invest in a public health strategy to counteract the spread of antibiotic-resistant bacterial infections.

\section{The Drug Target Approach}

The rapid progress in microbial genome sequencing has provided important clues to the identification of bacterial virulence factors, host specificity mechanisms, drug resistance phenomena, and genes encoding for microbial enzymes indispensable for corresponding metabolism (Selzer et al., 2000; Asif, 2012). Enzymes represent significant druggable targets since they are involved in decisive reaction catalyzing bacterial metabolic pathways, and thus are fundamental for microbe strength and virulence (Manchado et al., 2016; Sosa et al., 2018). In this context, the drug-approach method consists in: (i) the identification of essential metabolic pathways for pathogen life; (ii) the discovery of critical enzymes that are indispensable for bacterial catabolism and/or anabolism processes; (iii) the discovery of small molecules and/or peptides able interfering in vitro and in vivo with the activity of the target enzyme, and ultimately with microbial growth (Manchado et al., 2016). In general, the condition of identifying target enzymes that are present only in the microbes and not in the host is optimal for pharmaceutical purposes; for example, this situation occurs in the case of natural/synthetic molecules interfering with biosynthesis of bacterial peptidoglycan structure, which is absent in mammalian cells. However, this condition is uncommon due to the general conservation of most important metabolic pathways in all organisms. In the latter case, this limitation is overcome by designing/isolating molecules selectively inhibiting bacterial enzymes and not host protein homologs. For example, trimethoprim was found to selectively inhibit the bacterial enzyme dihydrofolate reductase (DHFR), which is ubiquitously expressed in all living organisms, but not human DHFR (Capasso and Supuran, 2014). Using NADPH as an electron donor, DHFR reduces the dihydrofolic acid (DHF) to tetrahydrofolic acid (THF). THF is the cofactor of several reactions concerning the synthesis of amino acids and nucleic acids (i.e., purines, thymidylate, methionine, glycine, pantothenic acid, and $\mathrm{N}$-formyl-methionyl tRNA) (Capasso and Supuran, 2014). Besides, the amino acid sequence of bacterial DHFR reveals $30 \%$ of identity when compared with the human protein, and this phenomenon was associated with drug selectivity.

\section{BACTERIAL CARBONIC ANHYDRASES AS DRUGGABLE TARGETS}

The genome exploration of microorganisms causing mammalian and non-mammalian infections as well as the genome of those considered not harmful evidenced genes encoding for an exciting class of enzymes that are involved in the metabolic balance of the bacterial carbon dioxide $\left(\mathrm{CO}_{2}\right)$, bicarbonate $\left(\mathrm{HCO}_{3}{ }^{-}\right)$, and protons $\left(\mathrm{H}^{+}\right)$(Annunziato et al., 2016; Capasso and Supuran, 2016; Del Prete et al., 2016a,b; Ozensoy Guler et al., 2016), namely carbonic anhydrases (CAs, EC 4.2.1.1). They belong to a superfamily of metalloenzymes that catalyze the physiologically 
crucial reversible reaction of $\mathrm{CO}_{2}$ hydration to $\mathrm{HCO}_{3}{ }^{-}$and $\mathrm{H}^{+}$, according to the following chemical reaction (Capasso and Supuran, 2015a):

$$
\mathrm{CO}_{2}+\mathrm{H}_{2} \mathrm{O} \leftrightharpoons \mathrm{HCO}_{3}^{-}+\mathrm{H}^{+}
$$

Until now, eight CA classes indicated with $\alpha, \beta, \gamma, \delta, \zeta, \eta, \theta$, and $\iota$ have been described in all kingdoms of living organisms (Supuran and Capasso, 2017). All CA classes strictly conserve the $\mathrm{CO}_{2}$ hydration and $\mathrm{HCO}_{3}{ }^{-}$dehydration mechanisms, showing an evident phenomenon of convergent evolution, having a very low sequence similarity, and different 3D molecular folds and structures (Supuran and Capasso, 2017). In Bacteria, four CAclasses $(\alpha, \beta, \gamma$, and $\iota)$ regulate the $\mathrm{CO}_{2}$ and $\mathrm{HCO}_{3}{ }^{-}$balance, being the only CA classes encoded by the bacterial genome (Capasso and Supuran, 2013, 2015b,c; Supuran and Capasso, 2015; Del Prete et al., 2020b). For enzyme catalysis, most of these CAs need $\mathrm{Zn}^{2+}$ as ion cofactor, which is coordinated by three amino acid residues from the protein backbone (Buzas and Supuran, 2016; Supuran, 2016e). The fourth metal ion ligand is a water molecule/hydroxide ion acting as the nucleophile in enzyme catalytic cycle (Carta et al., 2014). In particular, $\gamma$-CAs are $\mathrm{Fe}^{2+}$-dependent enzymes, but they are also active with bound $\mathrm{Zn}^{2+}$ or $\mathrm{Co}^{2+}$ ions; the last identified $\mathrm{l-CA}$ class from the marine diatom Thalassiosira pseudonana prefers $\mathrm{Mn}^{2+}$ to $\mathrm{Zn}^{2+}$ as the ion cofactor. $\alpha$-CAs are usually active as monomers or dimers; $\beta$-CAs are active only as dimers, tetramers, or octamers. The $\gamma$-CAs must be trimers for accomplishing their catalytic function (Di Fiore et al., 2013; De Simone et al., 2015; Ferraroni et al., 2015; Lomelino et al., 2016a). $\gamma$-CA monomers are characterized by a tandemly-repeated hexapeptide crucial for the left-hand fold of the trimeric $\beta$-helix structures (Fu et al., 2008). The X-ray structure of $\mathrm{l}$-CAs is not available at this moment. Intriguing, $\alpha$ and $\mathrm{\iota -CAs}$ catalyze also ester/thioester reactions (Supuran, 2016c; Jensen et al., 2019).

\section{Role of Bacterial CAs and Their Relationship With the Bacterial Lifecycle}

At a physiological $\mathrm{pH}$ value, the naturally occurring $\mathrm{CO}_{2}$ hydration reaction is too slow, with a first-order rate constant of $0.15 \mathrm{~s}^{-1}$, while a rate constant of $50 \mathrm{~s}^{-1}$ was shown by the reverse reaction (Supuran and Capasso, 2017). Thus, the CA activity is connected to a very rapid process, such as that related to the transport and supply of $\mathrm{CO}_{2}$ or $\mathrm{HCO}_{3}{ }^{-}$, which is generally essential for a number of physiological mechanisms, such as $\mathrm{pH}$ homeostasis, secretion of electrolytes, biosynthetic processes, photosynthesis, and others (Supuran and Capasso, 2018, 2020). These processes may not be supported by the uncatalyzed reversible $\mathrm{CO}_{2}$ hydration reaction characterized, as noted above, by very low catalytic constants.

The presence of multiple CA genes supports the crucial role of these enzymes in prokaryotic physiology. In Gramnegative bacteria, we initially proposed that $\alpha$-CAs, which are typified by a signal peptide at the $N$-terminus of the polypeptide chain, occur in the periplasmic space where they convert the $\mathrm{CO}_{2}$ to bicarbonate that diffuses in this environment, ensuring the microbe lifecycle (Capasso and Supuran, 2015a,
2016). In contrast, the $\beta$ - or $\gamma$-classes are localized into the cytoplasm, accomplishing various intracellular functions, such as $\mathrm{CO}_{2} / \mathrm{HCO}_{3}{ }^{-}$transport, $\mathrm{pH}$ balancing, and other (Supuran and Capasso, 2016, 2020). Recently, the existence of a short putative signal peptide at the protein $N$-terminus of some $\beta$ - and $\gamma$-CAs from Gram-negative bacteria was also demonstrated; similarly, it was observed that $\mathrm{l-CAs}$ in the Gram-negative bacterium Burkholderia territorii also present a signal peptide (Del Prete et al., 2020a). Whenever characterized by a signal peptide, $\beta-, \gamma-$, and $\mathrm{\iota}$-CAs might thus localized in the periplasmic space, having a function similar to that performed by $\alpha$-CAs. Finally, taking advantage of protonography and mass spectrometry, members of $\alpha$-CA class were also ascertained to occur in the outer membrane vesicles (OMVs) generated $H$. pylori strains in the planktonic and biofilm phenotypes (Ronci et al., 2019), underlying the existence of additional secretion mechanisms for these enzymes.

By affecting $\mathrm{CO}_{2} / \mathrm{HCO}_{3}{ }^{-}$balance, it was demonstrated that CA activity influences a number of pivotal bacterial processes. For example, it was verified that the deletion of the gene encoding for the $\beta$-CA in Ralstonia eutropha is associated with an heterotrophic growth of the bacterial mutant only when elevated $\mathrm{CO}_{2}$ concentrations occur (Kusian et al., 2002). In Escherichia coli, $\beta$-CA (CynT) catalyzes the hydration of $\mathrm{CO}_{2}$ generated by cyanase and generates $\mathrm{HCO}_{3}{ }^{-}$, thus preventing final $\mathrm{HCO}_{3}{ }^{-}$depletion in bacteria resulting from degradation of cyanate and/or other metabolic processes. Besides, a second $\beta$-CA (CynT2) was discovered in E. coli, which was demonstrated being essential for the microorganism growth at atmospheric $\mathrm{CO}_{2}$ (Cronk et al., 2001; Merlin et al., 2003). Finally, bacteria belonging to the genera Buchnera and Rickettsia were demonstrated being adapted to live only in niches characterized by high $\mathrm{CO}_{2}$ levels, and this adaptation is generally accompanied by loss of genes encoding for CAs (Ueda et al., 2012).

On the other hand, a number of examples are present in the literature concerning the relationship between CA activity and survival, pathogenicity, and virulence of several human pathogenic species. For example, the genome of $V$. cholerae, the Gram-negative bacterium responsible for cholera, was shown to encode for CAs of the $\beta$-, and $\gamma$-type, which are all involved in the production of sodium bicarbonate, a potent inducer of the cholera toxin (Abuaita and Withey, 2009). Similarly, two $\beta$ CA from B. suis, a Gram-negative coccobacillus responsible for brucellosis, and three $\beta$-CAs (mtCA1, mtCA 2 and mtCA3) from M. tuberculosis (Nishimori et al., 2010), the causative agent of tuberculosis, were demonstrated being essential for the growth of the corresponding microbes (Carta et al., 2009; Ceruso et al., 2014; Singh and Supuran, 2014; Kohler et al., 2017). Analogously, the genome of S. enterica serovar Typhimurium, a Gram-negative bacterium causing gastroenteritis (Rollenhagen and Bumann, 2006), also encodes for a $\beta$-CA (Nishimori et al., 2011; Vullo et al., 2011) that is highly expressed during the bacterial infection, as demonstrated by in vivo gene expression studies (Rollenhagen and Bumann, 2006). In P. aeruginosa (psCA1), a Gram-negative bacterium commonly found in the environment, the $\beta$-CA gene's deletion provoked a reduction of calcium salt depositions, impairing the microbe virulence (Lotlikar et al., 2019). Finally, it was demonstrated that various CAs encoded by the H. pylori 
genome are essential for the acid tolerance/adaptation of the microbe in the stomach, a harsh environment with $\mathrm{pH}$ values as low as 1-2 (Buzas, 2010; Modak et al., 2019).

\section{Inhibition of Bacterial CAs}

With their activity, CAs continually provide the indispensable $\mathrm{CO}_{2}$ and $\mathrm{HCO}_{3}{ }^{-}$/protons to microbial biosynthetic pathways. Thus, it is immediately apparent that their inhibition might impair the survival of pathogens. CA inhibitors (CAIs) belonging to many chemical classes are known and a description is reported below.

\section{Substituted Benzene-Sulfonamides and Clinically Licensed Drugs}

The initial antimicrobial products commonly used in healthcare environments were the sulfonamides discovered by Domagk in 1935 (Otten, 1986). Prontosil was the first sulfonamide to demonstrate an intense antibacterial activity. It is a sulfanilamide prodrug, which is isosteric/isostructural with $p$-aminobenzoic acid (PABA), the substrate of dihydropteroate synthase (DHPS) (Achari et al., 1997). DHPS is a critical enzyme for folate synthesis, an essential vitamin/nutrient that mammals get from their diet. Differently from mammals, bacteria use DHPS to synthesize folate through the chemical reaction among DHPP and PABA. After sulfanilamide was demonstrated to be an effective antibacterial agent, many analogs (the sulfa drugs) entered clinical use. Today, these compounds are still used although knowing drug resistance issues. DHPS, as mentioned above, is the target of the sulfa drugs, which work because they fit into the DHPS active site and take PABA's place. Several DHPS mutations are responsible for sulfonamide resistance (Capasso and Supuran, 2014). Sulfa drugs are derived from sulfonamides, and the presence of primary sulfonamide moieties in sulfanilamide characterizes most of the investigated CA inhibitors (CAIs) (Supuran, 2016a,b, 2017a). Sulfonamides and their structurally related derivatives, such as sulfamates and sulfamides, have the general formula $\mathrm{A}-\mathrm{SO}_{2} \mathrm{NH}-\mathrm{R}$, where A can be an aromatic, heterocyclic, aliphatic, or sugar scaffold, while $\mathrm{R}$ may be hydrogen (primary sulfonamides/sulfamates/sulfamides), or a multiplicity of moieties incorporating heteroatoms $(-\mathrm{OH}$, $-\mathrm{NH}_{2}$, etc.), as well as organic scaffolds like those said for A. Thus, a range of compounds containing the $-\mathrm{SO}_{2} \mathrm{NH}_{2}$ group were investigated as CAIs against bacterial CAs or CAs from other organisms (Supuran, 2017b). Figure 1 shows some
A
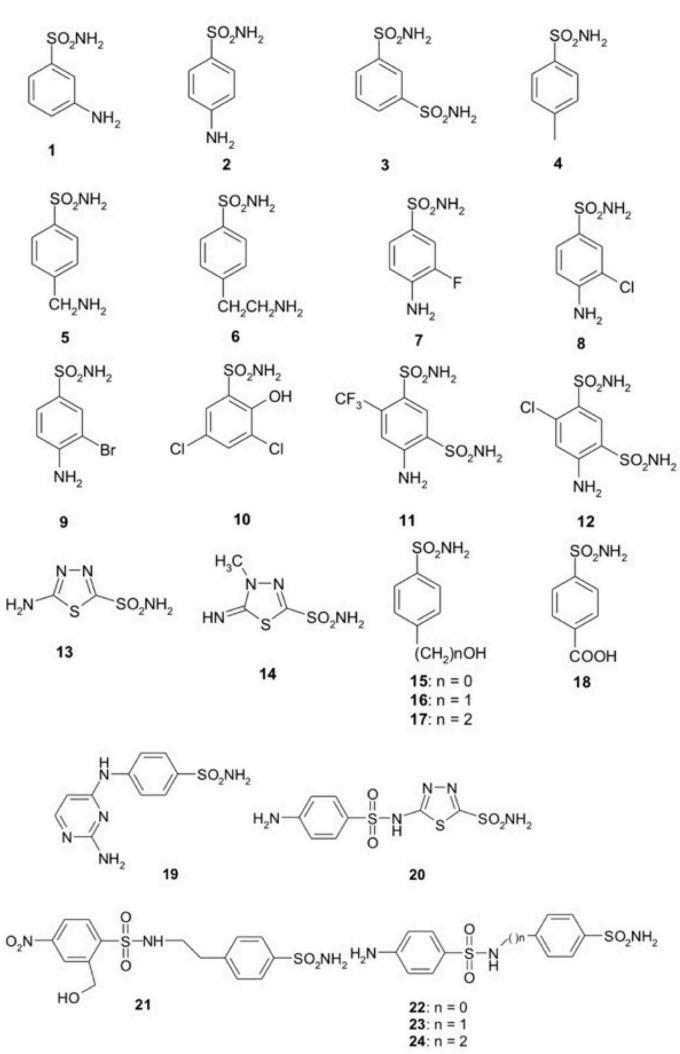

B
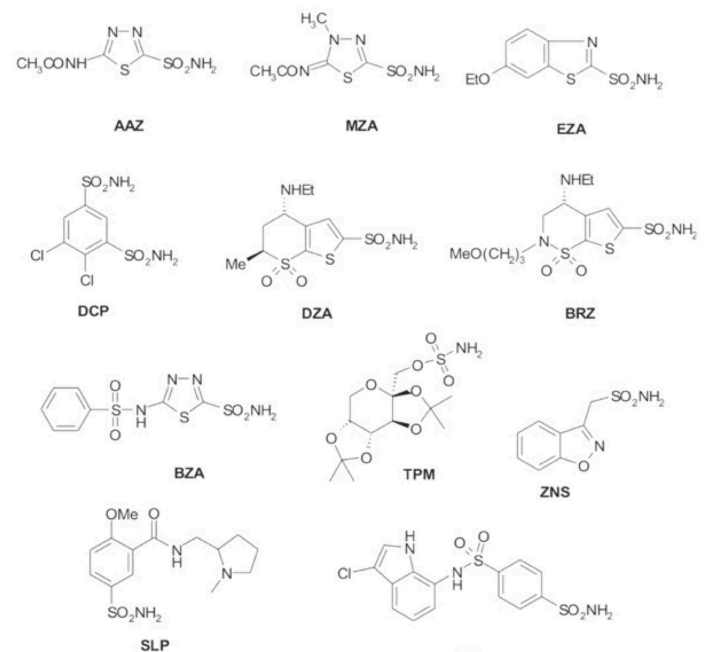

SLP
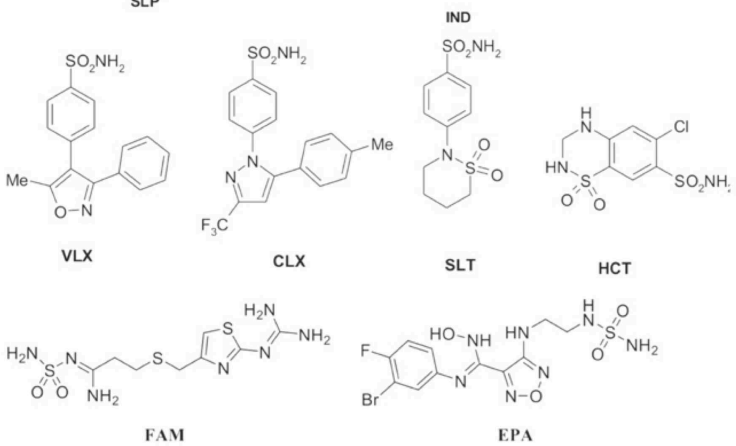

FIGURE 1 | Sulfonamides and their isostere classes (sulfamates and sulfamides) as CAls. Simple aromatic/heterocyclic derivatives 1-24 (A); clinically used drugs or agents in clinical development (B). 
of these sulfonamide inhibitors (simple derivatives 1-24 and clinically used drugs or agents in clinical development) (Carta et al., 2009; Nishimori et al., 2010, 2014; Vullo et al., 2013, 2015a,b,c; Alafeefy et al., 2015a,b; Dedeoglu et al., 2015; Abdel Gawad et al., 2016; Del Prete et al., 2016b,c,d; Diaz et al., 2016; Supuran, 2016d). Acetazolamide (AAZ), methazolamide (MZA), ethoxzolamide (EZA) and dichlorophenamide (DCP) are systemically acting antiglaucoma CAIs. Dorzolamide (DZA) and brinzolamide (BRZ) are antiglaucoma agents that function topically; benzolamide (BZA) is an orphan drug of this pharmacological class. Some of these compounds, such as topiramate (TPM), sulthiame (SLT), and zonisamide (ZNS), are antiepileptic drugs in clinical use for several decades. Other sulfonamides, such as the clinically used sulpiride (SLP) and the antitumor agent indisulam (IND), no longer in clinical development, along with the sulfonamides originally developed as COX-2 selective inhibitors [celecoxib (CLX) and valdecoxib (VLX)] were also included in our experiments. Other investigated compounds as CAIs are saccharin (SAC), hydrochlorothiazide (HCT), a thiazide diuretic (Supuran, 2008), famotidine (FAM), a histamine $\mathrm{H}_{2}$-receptor antagonist (Nguyen et al., 2020), as well as the experimental agent epacadostat (EPA), which acts as an inhibitor indoleamine 2,3-dioxygenase-1 (IDO1), a hemecontaining enzyme (Komiya and Huang, 2018). All of them were shown to also act as CAIs primary sulfonamides as these ones inhibit CAs by binding to the $\mathrm{Zn}^{2+}$ ion from the enzyme active site, in a tetrahedral geometry of the metal, whereas the sulfonamide is deprotonated at the $\mathrm{SO}_{2} \mathrm{NH}_{2}$ moiety. The nitrogen atom of the $\mathrm{SO}_{2} \mathrm{NH}^{-}$group then coordinates the $\mathrm{Zn}^{2+}$ ion, and participates to a network of $\mathrm{H}$-bonds, which involve conserved amino acid residues (Thr199 and Glu106), which in this way anchor the inhibitor molecule to the enzyme very strongly. This has been demonstrated by X-ray crystallographic studies of many adducts of such sulfonamides with various CA isoforms. The scaffold of the inhibitor (aromatic/heterocyclic moiety) also interacts with amino acid residues from the active site, either in the hydrophilic or within the hydrophobic part of the catalytic cleft.

\section{Inorganic Metal-Complexing Anions}

Anions or complex molecules (such as carboxylates) can bind CAs (De Simone and Supuran, 2012). Anions may bind either to the metal ion in the tetrahedral geometry or as trigonal-bipyramidal adducts. Anion inhibitors are generally millimolar or submillimolar CAIs; they are thus less effective than sulfonamides, which may show $\mathrm{K}_{\mathrm{Is}}$ in the submicromolar to the nanomolar range. However, the anion inhibition profile is essential for the comprehension of the cellular physiological processes, which see involved the CAs, as well as for the production of new forms of selective and efficient inhibitors; the latter ones may be useful in the treatment of disease caused by an alteration in the CA activity.

\section{Dithiocarbamates}

Other CAIs investigated as antibacterials are made of dithiocarbamates (DTCs) (Scozzafava et al., 2000, 2001; Carta et al., 2012a,b; Monti et al., 2012; Maresca et al., 2013).
These CAIs discovered after the inorganic anion trithiocarbonate $\left(\mathrm{CS}_{3}{ }^{2-}\right.$, TTC) have been evaluated by using kinetic and X-ray crystallographic studies, for understanding the binding of this relatively weak inhibitor to the human isoform hCA II (Innocenti et al., 2010). Afterward, it has been demonstrated that, due to the fact that both DTCs, similar to TTC, incorporate the $\mathrm{CS}_{2}{ }^{-}$ fragment, they bind through one of the sulfur atoms to the $\mathrm{Zn}^{2+}$ ion from the CA active site, interacting also with the conserved residues mentioned above in all $\alpha$-CAs, Thr199, and Glu106. DTCs act as micromolar-low nanomolar CAIs against many isoforms, since their organic scaffold was observed to participate in various interactions with the CA active site (Adak et al., 2010; Supuran, 2012; McKenna and Supuran, 2014).

\section{Carboxylic Acids}

Carboxylic acids are a group of non-classical CA inhibitors, which include among others phenols, polyamines, fullerenes, coumarins and their derivatives (Lomelino et al., 2016b). Aromatic carboxylic acids (e.g., compounds 25-38 in Figure 2) as well as aliphatic such derivatives (Figure 2B) inhibit CAs by various mechanisms; they can coordinate the catalytic ion cofactor as anions in a mono- or bidentate manner, or can anchor to the $\mathrm{Zn}^{2+}$-coordinated water. Carboxylates may have thus access to the catalytic zinc displacing the bound water/hydroxide or impairing its catalytic effectiveness due to anchoring to it. This binding is similar to that observed for phenol-based or polyamine CAIs, which has been documented by X-ray crystallography (Lomelino et al., 2016b).

\section{Helicobacter pylori AND ITS ADAPTATION IN THE STOMACH}

In 1979, examining the tissue samples from patients subjected to a gastric biopsy, the pathologist J. Robin Warren noted many spiral-shaped curved bacteria below the thick mucus layer, covering the stomach inner wall. Later, Warren associated this infection with chronic superficial gastritis, and the nested bacteria were identified as belonging to the genus Helicobacter (Warren, 2000, 2006). Today, we know that a high percentage of people infected with $H$. pylori have superficial chronic gastritis. Besides, if left untreated, both $H$. pylori infection and inflammation can persist for decades, and sometimes even for all the lifetime (Rahman et al., 2020). Over the years, it has learnt that H. pylori causes a chronic inflammatory process, the peptic ulcer in the stomach and duodenum, the portion of the small intestine that originates from the pylorus (Zhu et al., 2020). The infection, previously considered to be of metabolic origin, strongly increases the risk of neoplasms, such as adenocarcinomas and lymphomas. For example, it was discovered that some varieties of $H$. pylori have a $40 \mathrm{~kb}$ DNA insertion element called cag pathogenicity island (cag PAI), containing about 32 genes encoding the bacterial type IV secretion system (Noto and Peak, 2012). The cag system enables the transmission of bacterial effector molecules into the gastric epithelial cells of the host. Some H. pylori strains slowly inject into the gastric cells one of the virulent proteins, called 
A<smiles>O=C(O)c1ccc(F)cc1</smiles>

25<smiles>O=C(O)c1ccc([N+](=O)[O-])cc1</smiles>

29<smiles>O=C(O)c1ccc(Cl)cc1</smiles>

26<smiles>O=C(O)c1ccc(Br)cc1</smiles>

27

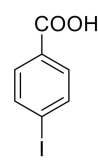

28<smiles>O=C(O)c1ccc(O)cc1</smiles>

30<smiles>COc1ccc(C(=O)O)cc1</smiles>

31
B

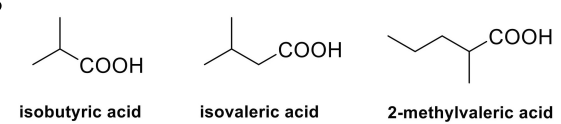

isobutyric acid isovaleric acid 2-methylvaleric acid
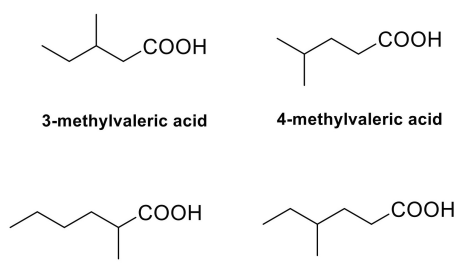

2-methylhexanoic acid
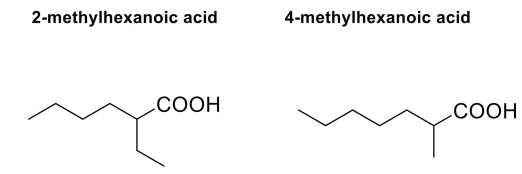

2-ethylhexanoic acid
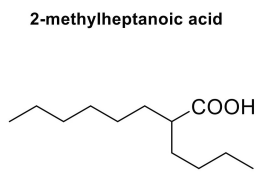

2-butyloctanoic acid<smiles>O=C(O)c1ccc(CCl)cc1</smiles>

36<smiles>CN(C)c1ccc(C(=O)O)cc1</smiles><smiles>CN(C)S(=O)(=O)c1ccc(C(=O)O)cc1</smiles>

37

38

FIGURE 2 | Carboxylic acids investigated as bacterial CAls. Aromatic carboxylic acids 25-38 (A); aliphatic carboxylic acids (B)

CagA that can trigger severe gastritis atrophy, dysplasia, and gastric adenocarcinoma, when a comparison with counterpart strains lacking this component was done (Amieva et al., 2003; Ye et al., 2003).

Helicobacter pylori is a Gram-negative pathogenic neutralophilic bacterium with a metabolism harmonized for a neutral $\mathrm{pH}$ development, but it is adapted to live in the overly acidic gastrointestinal environment (Tarsia et al., 2018). H. pylori genome encodes for $\alpha$ - and $\beta$-CAs. The $\alpha$-CA (hp $\beta C A$ ) has a periplasmic localization, while the $\beta$-CA (hp $\beta C A)$ is localized in the cytoplasm. It was aforementioned that the activity of $H$. pylori CAs could be an additional adaptation of the bacterium in the high acidic gastrointestinal environment ( $\mathrm{pH}$ in the range 1-2). Urease and CAs are the two enzymatic systems used by the microbe for growing in this extreme environment (Capasso and Supuran, 2015a). These enzymes regulate the bacterial $\mathrm{pH}$ value determining an increase in the cytoplasm through ammonia production $\left(\mathrm{NH}_{3}\right)$. Urea goes into the cytoplasm through the urea channel under acidic conditions, where the urease converts it into $\mathrm{NH}_{3}$ and $\mathrm{CO}_{2}$. In the cytoplasm, resulting $\mathrm{CO}_{2}$ is then hydrated by $\beta$-CA, while the periplasmic $\alpha$-CA hydrates the $\mathrm{CO}_{2}$ diffused in the periplasm (Capasso and Supuran, 2015b). The produced ions $\left(\mathrm{H}^{+}\right)$by the CA-catalyzed reaction are used by $\mathrm{NH}_{3}$ to form $\mathrm{NH}_{4}{ }^{+}$in the periplasm and cytoplasm, which neutralizes the entering acid in the above environments (Morishita et al., 2008). The combined action of urease and CAs result in the acid acclimatization of the pathogen within the stomach.

\section{ENZYME ACTIVITY AND IN VITRO AND IN VIVO INHIBITION OF THE Helicobacter pylori CAs}

\section{Enzyme Activity}

Periplasmic hp $\beta C A$ and cytoplasmic hp $\beta C A$ are catalytically efficient for the $\mathrm{CO}_{2}$ hydration reaction with a $\mathrm{k}_{c a t}$ values in the order of $10^{5} \mathrm{~s}^{-1}$. This catalytic constant is quite close to the $\mathrm{k}_{\text {cat }}$ of human isoenzyme hCA I (Nishimori et al., 2008).

\section{Inhibition by Substituted Benzene-Sulfonamides and Clinically Licensed Drugs}

hp $\beta C A$ and hp $\beta C A$ were strongly inhibited by many sulfonamides/sulfamates 1-24 and AAZ-HCT (see Table 1) as well as by novel derivatives obtained by attaching 4-tert-butyl-phenylcarboxamido/sulfonamide tails to benzenesulfonamide/1,3,4-thiadiazole-2-sulfonamide scaffolds (Modak et al., 2015, 2016). Dorzolamide and simple 4-substituted 
benzenesulfonamides were feeble inhibitors ( $\left.K_{\mathrm{Is}} 873-4,360 \mathrm{nM}\right)$. Sulfanilamide, orthanilamide, some of their derivatives, and indisulam showed a more strong inhibitory effect ( $K_{\mathrm{Is}}$ 413-640 nM), whereas methazolamide, ethoxzolamide, dichlorophenamide, brinzolamide, topiramate, zonisamide, and others, worked as inhibitors of medium strength $\left(K_{\text {Is }} 105-\right.$ $378 \mathrm{nM}$ ) (Nishimori et al., 2007; Table 1). For example, hp $\beta C A$ was selectivity inhibited over the hCAII by acetazolamide, 4-amino-6-chloro-1,3-benzenedisulfonamide, 4-(2-aminopyrimidin-4-yl)-benzenesulfonamide ( $\mathrm{K}_{\mathrm{Is}}$ in the range of 20-96 $\mathrm{nM})$, and compounds incorporating lipophilic tails $\left(K_{\mathrm{Is}}=12-84\right.$ nM) (Nishimori et al., 2006). Intriguingly, the hydrophilic pocket of hp $\beta C A$ resulted more open with respect to that of hCA II. As a consequence, famotidine (FAM), an antiulcer drug incorporating a sulfamide, resulted in an excellent inhibition of hp $\beta C A$ (Angeli et al., 2018; Table 1).

\section{In vivo CA Inhibition}

The involvement of CAs in the acid acclimation of $H$. pylori in the human stomach has been documented by administering CAIs, which inhibited the acid-producing machinery within the gut (Supuran, 2008). For example, acetazolamide was administrated in 1960 to treat American patients affected by peptic ulcers before the modern anti-ulcer agents were available (Buzas and Supuran, 2016). In 1968, Puscas administrated acetazolamide (2-4 g/day) to many ulcer patients obtaining considerable success even if the treatments were associated with a range of side effects. Recently, it has been shown that acetazolamide administration (500 mg) to volunteers with active $H$. pylori infection reduced the ability of $H$. pylori to adapt/survive in the acid environment of the stomach (Shahidzadeh et al., 2005). Other than acetazolamide, ethoxzolamide (EZA) can be considered a potential drug for developing new anti-H. pylori inhibitors since it kills the bacterium in cell cultures (Modak et al., 2019). Besides, EZA resistance did not develop easily in the H. pylori strains (P12, SS1,m and 26695) used for the experiments, and the compound seems to target multiple pathways since resistance acquisition was due to mutations associated with other genes than CAs (Rahman et al., 2020). In this context, we stress the fact that, recently, it has been demonstrated that the well documented vancomycinresistant enterococci (VRE) might be addressed by targeting the Enterococcus CAs using a modified scaffold of acetazolamide (an inhibitor of the carbonic anhydrases) (Kaur et al., 2020). As a result, the authors identified two lead compounds having improved potency against clinical VRE strains (MIC from 0.007 to $1 \mu \mathrm{g} / \mathrm{mL})(117)$. It is readily apparent that these results support the proof-of-concept that CAIs can be considered as novel antibacterials.

\section{H.pylori OUTER MEMBRANE VESICLES}

The bacterial extracellular vesicles (EVs) are generated in a budding manner similar to that of the yeasts (Kim et al., 2015). Gram-negative bacteria, differently from the Gram-positive bacteria, produce extracellular vesicles by pinching off the outer membrane and, for this reason, are defined with the
TABLE 1 | Inhibition of human hCA I and hCA II isoforms as well as of $H$. pylori CAs (hp $\alpha \mathrm{CA}$ and $\mathrm{hp} \beta \mathrm{CA}$ ) with sulfonamides 1-24 and the clinically used drugs AAZ-FAM.

\begin{tabular}{|c|c|c|c|c|}
\hline \multirow[t]{2}{*}{ Inhibitor } & \multicolumn{4}{|c|}{$K_{l}^{c}(\mathrm{nM})$} \\
\hline & hCA I & hCA IIa & $\mathrm{hp} \alpha \mathrm{CA}^{\mathrm{a}}$ & $h p \beta C A^{b}$ \\
\hline 1 & 45,400 & 295 & 426 & 16,400 \\
\hline 2 & 25,000 & 240 & 454 & 1,845 \\
\hline 3 & 28,000 & 300 & 316 & 8,650 \\
\hline 4 & 78,500 & 320 & 430 & 2,470 \\
\hline 5 & 25,000 & 170 & 873 & 2,360 \\
\hline 6 & 21,000 & 160 & 1,150 & 3,500 \\
\hline 7 & 8,300 & 60 & 1,230 & 1,359 \\
\hline 8 & 9,800 & 110 & 378 & 1,463 \\
\hline 9 & 6,500 & 40 & 452 & 1,235 \\
\hline 10 & 6,000 & 70 & 510 & 1,146 \\
\hline 11 & 5,800 & 63 & 412 & 973 \\
\hline 12 & 8,400 & 75 & 49 & 640 \\
\hline 13 & 8,600 & 60 & 323 & 2,590 \\
\hline 14 & 9,300 & 19 & 549 & 768 \\
\hline 15 & 6 & 2 & 268 & 64 \\
\hline 16 & 164 & 46 & 131 & 87 \\
\hline 17 & 185 & 50 & 114 & 71 \\
\hline 18 & 109 & 33 & 84 & 38 \\
\hline 19 & 95 & 30 & 207 & 39 \\
\hline 20 & 690 & 12 & 105 & 37 \\
\hline 21 & 55 & 80 & 876 & 236 \\
\hline 22 & 21,000 & 125 & 1,134 & 218 \\
\hline 23 & 23,000 & 133 & 1,052 & 450 \\
\hline 24 & 24,000 & 125 & 541 & 15,250 \\
\hline AAZ & 250 & 12 & 21 & 40 \\
\hline MZA & 50 & 14 & 225 & 176 \\
\hline EZA & 25 & 8 & 193 & 33 \\
\hline DCP & 1,200 & 38 & 378 & 105 \\
\hline DZA & 50,000 & 9 & 4,360 & 73 \\
\hline BRZ & 45,000 & 3 & 210 & 128 \\
\hline BZA & 15 & 9 & 315 & 54 \\
\hline TPM & 250 & 10 & 172 & 32 \\
\hline ZNS & 56 & 35 & 231 & 254 \\
\hline SLP & 1,200 & 40 & 204 & 35 \\
\hline IND & 31 & 15 & 413 & 143 \\
\hline FAM & 922 & 58 & 21 & 50 \\
\hline
\end{tabular}

a Human/bacterial recombinant isozymes and stopped-flow $\mathrm{CO}_{2}$ hydrase assay method, as reported in Nishimori et al. (2008).

${ }^{b}$ Recombinant hpCA and stopped-flow $\mathrm{CO}_{2}$ hydrase assay method, as reported in this work, mean \pm SE (from three different assays) and in Nishimori et al. (2007). ${ }^{c}$ Errors in the range of $5-10 \%$ of the shown data, as resulting from three different assays.

acronym OMVs (Outer Membrane Vesicles) (Liu et al., 2018). Distinctive features of OMVs are the lipopolysaccharide (LPS) and encapsulate periplasmic components, which are absent in the Gram-positive EVs. The vesicles generated by Grampositive bacteria could bring inside various molecules, including nucleic acids, proteins, lipids, viruses, enzymes, and toxins. Depending molecules contained inside, these vesicles can have variegated roles. For example, they are involved in horizontal 
gene transfer, antibiotic resistance, microbial survival, microbial competition, nutrient acquisition, health benefits for the host, microbial virulence, cell-cell communication among bacteria and hosts, and biofilm formation (Ronci et al., 2019). The H. pylori OMVs are implicated in biofilm formation, and the presence of DNA inside these vesicles appears to be involved in "joining" OMV-OMV and OMV-cell communications (Grande et al., 2012, 2015). As aforementioned, Ronci et al. used mass spectrometry to identify periplasmic $\beta$-CA in the $H$. pylori OMVs generated in vitro from the microbe both in its planktonic and biofilm phenotypes (Ronci et al., 2019). Besides, $\beta$-CA hydratase activity was determined using the protonography, a technique selective for the detection of CAs. As a result, it was demonstrated that the amount of the periplasmic $\beta$-CA was higher in the planktonic OMVs (pOMVs) than in the biofilm OMVs (bOMVs). Furthermore, it was observed that the content of $\beta$-CA increased in pOMVs over time.

Moreover, the biofilm phenotype, a complex structure in which bacteria adhere to a surface and are embedded in a self-produced EPS (extracellular polymeric substance) matrix, is a condition used by pathogenic bacteria to improve their survival, bacterial infection, and resistance to the effects of antimicrobial agents (Parsek and Singh, 2003; Grande et al., 2014). H. pylori tends to form a biofilm on human gastric mucosa (Yonezawa et al., 2015), and biofilm cells are more resistant to the effects of antimicrobial agents (Carron et al., 2006). Generally, the first-line therapy to eradicate $H$. pylori infection is based on a combination of drugs, such as proton pump inhibitor (PPIs), amoxicillin, clarithromycin (CAM) or metronidazole, and fluoroquinolones (Bang et al., 2020). Novel approaches to prevent biofilm formation and to treat infections by biofilmforming bacteria are currently under development (Bjarnsholt et al., 2018). The identification of periplasmic $\beta$-CA in pOMVs and its specific inhibition with the classical CAIs might shed new light on this enzyme's role in the $H$. pylori colonization, survival, persistence, and pathogenesis.

\section{CA INHIBITORS IN COMBINATION WITH PROBIOTIC STRAINS}

In the literature, it has been reported the possible existence of a correlation between intestinal microbiota (i.e., microbial populations living in the intestine) and various autoimmune diseases, such as systemic lupus erythematosus or autoimmune liver diseases (Manfredo Vieira et al., 2018). Kriegel and colleagues noted that the bacterium Enterococcus gallinarum, a very rare enterococcus, has been often identified in the intestinal flora and liver of patients with lupus; thus, it was considered as a trigger of the systemic lupus erythematosus (Manfredo Vieira et al., 2018). In experiments on mice, it was demonstrated that these bacteria can overcome the small intestine barrier and quickly reach the liver and other organs, particularly the spleen and lymph nodes. In this way, the bacterium triggers an inflammatory process, which allows the secretion of chemical messengers equal to those observed in subjects with lupus, inducing the proliferation of autoantibodies that also attack the cells of the organism. In contrast, some bacterial strains, which live within the microbiota, function as brakes against intestinal tumors (Zagato et al., 2020). For example, it has been observed the absence of Holdemanella biformis, a bacterium belonging to the family of Erysipelotrichaceae, in the microbiota of patients in an early stage of development of intestinal cancer. These bacteria have antitumor properties capable of blocking the uncontrolled proliferation of cells, which happens in the case of a lack of them in the gut (Zagato et al., 2020). Thus, it is reasonable to believe that these anti-tumorigenic bacteria have a strong diagnostic, therapeutic, and translational potential.

In H. pylori-infected individuals, the gastric microbiota is similar to that of the non-infected persons. In general, infected persons have $52.6 \%$ of Proteobacteria, $26.4 \%$ of Firmicutes, $12 \%$ of Bacteroidetes and 6.4\% of Actinobacteria (Llorca et al., 2017; Ozbey et al., 2020). The resident gastric microflora may interfere with $H$. pylori's proliferation and gut disease. For this reason, the pharmacological treatments for eradicating $H$. pylori from the gastric mucosa can be ameliorate using probiotics (Emara et al., 2014; Maccelli et al., 2020). The effect of new antimicrobial molecules is rarely evaluated; thus, the identification of new drugs that possess a selective toxicity between pathogens and some components of the human microbiota might represent an important step in the clinical field (Grande et al., 2020). Therefore, the identification of probiotic strains, which do not possess the CAs and constitute a significant component of the human microbiota (Martin et al., 2013) used in combination with innovative drugs, such as those coming from the modified scaffold of CAIs, might represent an innovative anti-H. pylori treatment. Not being affected by the inhibitor, the probiotic can exert a synergistic effect improving the antimicrobial action of the (bactericidal or bacteriostatic) CA inhibitors. Besides, the probiotic, by educating or stimulating the host immune system, could also contribute to the efficacy of the CA inhibitor. Thus, this combination might represent an innovative and successful strategy to fight infections without altering the normal microbiota.

\section{CONCLUSION}

At least four classes of CAs $(\alpha, \beta, \gamma$, and $\iota)$ are present in Bacteria. During growth, microbes require $\mathrm{CO}_{2}$ and $\mathrm{HCO}_{3}{ }^{-}$to support their metabolism, as well as $\mathrm{H}^{+}$ions/bicarbonate for the balance of the $\mathrm{pH}$ value. CAs with their activity correctly balance the interconversion of inorganic these species. Thus, CAs play essential roles in the life cycle of pathogenic and nonpathogenic bacteria, and their inhibition prejudices the growth of the microbe. This paves the way for designing novel anti-infective drugs, which function differently from the standard antibiotics. The involvement of CAs in the lifecycle, pathogenicity, and virulence of several species (e.g., H. pylori, V. cholerae, B. suis, S. enterica, P. aeruginosa, and Enterococcus spp.) of human pathogens is not new, but only recently programs to develop agents that specifically and selectively inhibit these enzymes have been initiated. Presently, many bacterial species have been investigated for the presence of CAs belonging to all four classes 
mentioned above. Furthermore, many bacterial CAs have been prepared as recombinant enzymes and thoroughly characterized by a biochemical viewpoint and for their ability to be inhibited by various compounds. These enzymes were effectively inhibited by the classical CAIs, such as the sulfonamides and their derivatives, sulfamates, sulfamides, (in)organic anions, and some of them by dithiocarbamates as well as carboxylic acids. More exciting is the discovery that ethoxzolamide can kill $H$. pylori in vitro and in vivo, and that the bacterial resistance to this compound does not develop easily. The recent study on the efficacy of acetazolamide and some of its derivatives to act as inhibitors of vancomycin resistant enterococci (VRE) is a breakthrough in the field (Kaur et al., 2020). The drug design campaign reported in the same study led to the identification of sulfonamide derivatives, which seem to be orders of magnitude more efficient against VRE, when compared to the clinically used agent linezolid. Drug design campaigns were also useful in finding $H$. pylori-selective CAIs

\section{REFERENCES}

Abdel Gawad, N. M., Amin, N. H., Elsaadi, M. T., Mohamed, F. M., Angeli, A., De Luca, V., et al. (2016). Synthesis of 4-(thiazol-2-ylamino)-benzenesulfonamides with carbonic anhydrase I, II and IX inhibitory activity and cytotoxic effects against breast cancer cell lines. Bioorg. Med. Chem. 24, 3043-3051. doi: 10.1016/ j.bmc.2016.05.016

Abuaita, B. H., and Withey, J. H. (2009). Bicarbonate induces Vibrio cholerae virulence gene expression by enhancing ToxT activity. Infect. Immun. 77, 4111-4120. doi: 10.1128/IAI.00409-09

Achari, A., Somers, D. O., Champness, J. N., Bryant, P. K., Rosemond, J., and Stammers, D. K. (1997). Crystal structure of the anti-bacterial sulfonamide drug target dihydropteroate synthase. Nat. Struct. Biol. 4, 490-497. doi: 10.1038/ nsb0697-490

Adak, A. K., Leonov, A. P., Ding, N., Thundimadathil, J., Kularatne, S., Low, P. S., et al. (2010). Bishydrazide glycoconjugates for lectin recognition and capture of bacterial pathogens. Bioconjug. Chem. 21, 2065-2075. doi: 10.1021/bc10 $0288 \mathrm{c}$

Ahl, A. S., and Buntain, B. (1997). Risk and the food safety chain: animal health, public health and the environment. Rev. Sci. Tech. 16, 322-330. doi: 10.20506/ rst.16.2.1018

Alafeefy, A. M., Abdel-Aziz, H. A., Vullo, D., Al-Tamimi, A. M., Awaad, A. S., Mohamed, M. A., et al. (2015a). Inhibition of human carbonic anhydrase isozymes I, II, IX and XII with a new series of sulfonamides incorporating aroylhydrazone-, $[1,2,4]$ triazolo[3,4-b][1,3,4] thiadiazinyl- or 2(cyanophenylmethylene)-1,3,4-thiadiazol-3(2H)-yl moieties. J. Enzyme Inhib. Med. Chem. 30, 52-56. doi: 10.3109/14756366.2013.877897

Alafeefy, A. M., Ceruso, M., Al-Tamimi, A. M., Del Prete, S., Supuran, C. T., and Capasso, C. (2015b). Inhibition studies of quinazoline-sulfonamide derivatives against the gamma-CA (PgiCA) from the pathogenic bacterium, Porphyromonas gingivalis. J. Enzyme Inhib. Med. Chem. 30, 592-596. doi: 10.3109/14756366.2014.957202

Amieva, M. R., Vogelmann, R., Covacci, A., Tompkins, L. S., Nelson, W. J., and Falkow, S. (2003). Disruption of the epithelial apical-junctional complex by Helicobacter pylori CagA. Science 300, 1430-1434. doi: 10.1126/science. 1081919

Angeli, A., Ferraroni, M., and Supuran, C. T. (2018). Famotidine, an antiulcer agent, srongly inhibits Helicobacter pylori and human carbonic anhydrases. ACS Med. Chem. Lett. 9, 1035-1038. doi: 10.1021/acsmedchemlett.8b00334

Annunziato, G. (2019). Strategies to overcome antimicrobial resistance (AMR) making use of non-essential target inhibitors: a review. Int. J. Mol. Sci. 20:5844. doi: 10.3390/ijms20235844

Annunziato, G., Angeli, A., D’Alba, F., Bruno, A., Pieroni, M., Vullo, D., et al. (2016). Discovery of new potential anti-infective compounds based on carbonic anhydrase inhibitors by rational target-focused repurposing approaches. ChemMedChem 11, 1904-1914. doi: 10.1002/cmdc.201600180 belonging to the sulfonamide class. Thus, it is not impossible to hypothesize that the field of CAIs as anti-infectives may lead to relevant developments in the near future and future dedicated studies are necessary in this context.

\section{AUTHOR CONTRIBUTIONS}

All authors contributed to the article and approved the submitted version.

\section{FUNDING}

This research was funded by the Italian Ministry of Education, University and Research, project FISR2019_04819 BacCAD (to CTS, ClC, and SC).

Asif, M. (2012). A review of antimycobacterial drugs in development. Mini. Rev. Med. Chem. 12, 1404-1418. doi: 10.2174/138955712804586657

Bang, C. S., Lim, H., Jeong, H. M., Shin, W. G., Choi, J. H., Soh, J. S., et al. (2020). Amoxicillin or tetracycline in bismuth-containing quadruple therapy as firstline treatment for Helicobacter pylori infection. Gut Microbes 11, 1314-1323. doi: 10.1080/19490976.2020.1754118

Bjarnsholt, T., Buhlin, K., Dufrene, Y. F., Gomelsky, M., Moroni, A., Ramstedt, M., et al. (2018). Biofilm formation - what we can learn from recent developments. J. Intern. Med. 284, 332-345. doi: 10.1111/joim.12782

Buzas, G. M. (2010). Helicobacter pylori - 2010. Orv. Hetil. 151, 2003-2010. doi: 10.1556/oh.2010.28982

Buzas, G. M., and Supuran, C. T. (2016). The history and rationale of using carbonic anhydrase inhibitors in the treatment of peptic ulcers. in memoriam Ioan Puscas (1932-2015). J. Enzyme Inhib. Med. Chem. 31, 527-533. doi: $10.3109 / 14756366.2015 .1051042$

Capasso, C., and Supuran, C. T. (2013). Anti-infective carbonic anhydrase inhibitors: a patent and literature review. Expert Opin. Ther. Pat. 23, 693-704. doi: 10.1517/13543776.2013.778245

Capasso, C., and Supuran, C. T. (2014). Sulfa and trimethoprim-like drugs antimetabolites acting as carbonic anhydrase, dihydropteroate synthase and dihydrofolate reductase inhibitors. J. Enzyme Inhib. Med. Chem. 29, 379-387. doi: $10.3109 / 14756366.2013 .787422$

Capasso, C., and Supuran, C. T. (2015a). An overview of the alpha-, beta- and gamma-carbonic anhydrases from bacteria: can bacterial carbonic anhydrases shed new light on evolution of bacteria? J. Enzyme Inhib. Med. Chem. 30, 325-332. doi: 10.3109/14756366.2014.910202

Capasso, C., and Supuran, C. T. (2015b). An overview of the selectivity and efficiency of the bacterial carbonic anhydrase inhibitors. Curr. Med. Chem. 22, 2130-2139. doi: 10.1517/14728222.2015.1067685

Capasso, C., and Supuran, C. T. (2015c). Bacterial, fungal and protozoan carbonic anhydrases as drug targets. Expert Opin. Ther. Targets 19, 1689-1704. doi: $10.2174 / 0929867321666141012174921$

Capasso, C., and Supuran, C. T. (2016). An overview of the carbonic anhydrases from two pathogens of the oral cavity: Streptococcus mutans and Porphyromonas gingivalis. Curr. Top. Med. Chem. 16, 2359-2368. doi: 10.2174/ 1568026616666160413135522

Carradori, S., Di Giacomo, N., Lobefalo, M., Luisi, G., Campestre, C., and Sisto, F. (2020). Biofilm and quorum sensing inhibitors: the road so far. Expert Opin. Ther. Pat. 30, 917-930. doi: 10.1080/13543776.2020.1830059

Carron, M. A., Tran, V. R., Sugawa, C., and Coticchia, J. M. (2006). Identification of Helicobacter pylori biofilms in human gastric mucosa. J. Gastrointest. Surg. 10, 712-717. doi: 10.1016/j.gassur.2005.10.019

Carta, F., Aggarwal, M., Maresca, A., Scozzafava, A., McKenna, R., Masini, E., et al. (2012a). Dithiocarbamates strongly inhibit carbonic anhydrases and show antiglaucoma action in vivo. J. Med. Chem. 55, 1721-1730. doi: 10.1021/ jm300031j 
Carta, F., Aggarwal, M., Maresca, A., Scozzafava, A., McKenna, R., and Supuran, C. T. (2012b). Dithiocarbamates: a new class of carbonic anhydrase inhibitors. crystallographic and kinetic investigations. Chem. Commun. 48, 1868-1870. doi: $10.1039 / \mathrm{c} 2 \mathrm{cc} 16395 \mathrm{k}$

Carta, F., Maresca, A., Covarrubias, A. S., Mowbray, S. L., Jones, T. A., and Supuran, C. T. (2009). Carbonic anhydrase inhibitors. Characterization and inhibition studies of the most active beta-carbonic anhydrase from Mycobacterium tuberculosis, Rv3588c. Bioorg. Med. Chem. Lett. 19, 6649-6654. doi: 10.1016/j.bmcl.2009.10.009

Carta, F., Supuran, C. T., and Scozzafava, A. (2014). Sulfonamides and their isosters as carbonic anhydrase inhibitors. Future Med. Chem. 6, 1149-1165. doi: $10.4155 /$ fmc. 14.68

Ceruso, M., Vullo, D., Scozzafava, A., and Supuran, C. T. (2014). Sulfonamides incorporating fluorine and 1,3,5-triazine moieties are effective inhibitors of three beta-class carbonic anhydrases from Mycobacterium tuberculosis. J. Enzyme Inhib. Med. Chem. 29, 686-689. doi: 10.3109/14756366.2013.8 42233

Cheesman, M. J., Ilanko, A., Blonk, B., and Cock, I. E. (2017). Developing new antimicrobial therapies: are synergistic combinations of plant extracts/compounds with conventional antibiotics the solution? Pharmacogn. Rev. 11, 57-72. doi: 10.4103/phrev.phrev_21_17

Collignon, P. (2015). Antibiotic resistance: are we all doomed? Intern. Med. J. 45, 1109-1115. doi: 10.1111/imj.12902

Cronk, J. D., Endrizzi, J. A., Cronk, M. R., O’Neill, J. W., and Zhang, K. Y. (2001). Crystal structure of E. coli beta-carbonic anhydrase, an enzyme with an unusual pH-dependent activity. Protein Sci. 10, 911-922. doi: 10.1110/ps.46301

Dahle, U. R., and Petersen, F. C. (2013). Incentives for developing new antibiotics or antimicrobial strategies. BMJ 346:f2136. doi: 10.1136/bmj.f2136

De Simone, G., and Supuran, C. T. (2012). (In)organic anions as carbonic anhydrase inhibitors. J. Inorg. Biochem. 111, 117-129. doi: 10.1016/j.jinorgbio. 2011.11.017

De Simone, G., Monti, S. M., Alterio, V., Buonanno, M., De Luca, V., Rossi, M., et al. (2015). Crystal structure of the most catalytically effective carbonic anhydrase enzyme known, SazCA from the thermophilic bacterium Sulfurihydrogenibium azorense. Bioorg. Med. Chem. Lett. 25, 2002-2006. doi: 10.1016/j.bmcl.2015.02.068

Dedeoglu, N., DeLuca, V., Isik, S., Yildirim, H., Kockar, F., Capasso, C., et al. (2015). Sulfonamide inhibition study of the beta-class carbonic anhydrase from the caries producing pathogen Streptococcus mutans. Bioorg. Med. Chem. Lett. 25, 2291-2297. doi: 10.1016/j.bmcl.2015.04.037

Del Prete, S., De Luca, V., De Simone, G., Supuran, C. T., and Capasso, C. (2016a). Cloning, expression and purification of the complete domain of the eta-carbonic anhydrase from Plasmodium falciparum. J. Enzyme Inhib. Med. Chem. 31(Suppl. 4), 54-59. doi: 10.1080/14756366.2016.1217856

Del Prete, S., De Luca, V., Nocentini, A., Scaloni, A., Mastrolorenzo, M. D., Supuran, C. T., et al. (2020a). Anion inhibition studies of the betacarbonic anhydrase from Escherichia coli. Molecules 25:2564. doi: 10.3390/ molecules 25112564

Del Prete, S., Nocentini, A., Supuran, C. T., and Capasso, C. (2020b). Bacterial iota-carbonic anhydrase: a new active class of carbonic anhydrase identified in the genome of the Gram-negative bacterium Burkholderia territorii. J. Enzyme Inhib. Med. Chem. 35, 1060-1068. doi: 10.1080/14756366.2020.1755852

Del Prete, S., Vullo, D., De Luca, V., Carginale, V., Ferraroni, M., Osman, S. M., et al. (2016b). Sulfonamide inhibition studies of the beta-carbonic anhydrase from the pathogenic bacterium Vibrio cholerae. Bioorg. Med. Chem. 24, 11151120. doi: 10.1016/j.bmc.2016.01.037

Del Prete, S., Vullo, D., De Luca, V., Carginale, V., Osman, S. M., AlOthman, Z., et al. (2016c). Cloning, expression, purification and sulfonamide inhibition profile of the complete domain of the eta-carbonic anhydrase from Plasmodium falciparum. Bioorg. Med. Chem. Lett. 26, 4184-4190. doi: 10.1016/j.bmcl.2016. 07.060

Del Prete, S., Vullo, D., De Luca, V., Carginale, V., Osman, S. M., AlOthman, Z., et al. (2016d). Comparison of the sulfonamide inhibition profiles of the alpha-, beta- and gamma-carbonic anhydrases from the pathogenic bacterium Vibrio cholerae. Bioorg. Med. Chem. Lett. 26, 1941-1946. doi: 10.1016/j.bmcl.2016.03. 014

Di Fiore, A., Capasso, C., De Luca, V., Monti, S. M., Carginale, V., Supuran, C. T., et al. (2013). X-ray structure of the first 'extremo-alpha-carbonic anhydrase', a dimeric enzyme from the thermophilic bacterium Sulfurihydrogenibium yellowstonense YO3AOP1. Acta Crystallogr. D Biol. Crystallogr. 69(Pt 6), 11501159. doi: $10.1107 /$ S0907444913007208

Diaz, J. R., Fernandez Baldo, M., Echeverria, G., Baldoni, H., Vullo, D., Soria, D. B., et al. (2016). A substituted sulfonamide and its $\mathrm{Co}(\mathrm{II}), \mathrm{Cu}(\mathrm{II})$, and $\mathrm{Zn}$ (II) complexes as potential antifungal agents. J. Enzyme Inhib. Med. Chem. 31, 51-62.

Doyle, M. E. (2015). Multidrug-resistant pathogens in the food supply. Foodborne Pathog. Dis. 12, 261-279. doi: 10.1089/fpd.2014.1865

Emara, M. H., Mohamed, S. Y., and Abdel-Aziz, H. R. (2014). Lactobacillus reuteri in management of Helicobacter pylori infection in dyspeptic patients: a doubleblind placebo-controlled randomized clinical trial. Therap. Adv. Gastroenterol. 7, 4-13. doi: 10.1177/1756283X13503514

Fernando, S. A., Gray, T. J., and Gottlieb, T. (2017). Healthcare-acquired infections: prevention strategies. Intern. Med. J. 47, 1341-1351. doi: 10.1111/imj.13642

Ferraroni, M., Del Prete, S., Vullo, D., Capasso, C., and Supuran, C. T. (2015). Crystal structure and kinetic studies of a tetrameric type II beta-carbonic anhydrase from the pathogenic bacterium Vibrio cholerae. Acta Crystallogr. D Biol. Crystallogr. 71(Pt 12), 2449-2456. doi: 10.1107/S1399004715018635

Fu, X., Yu, L. J., Mao-Teng, L., Wei, L., Wu, C., and Yun-Feng, M. (2008). Evolution of structure in gamma-class carbonic anhydrase and structurally related proteins. Mol. Phylogenet. Evol. 47, 211-220. doi: 10.1016/j.ympev.2008. 01.005

Grande, R., Di Campli, E., Di Bartolomeo, S., Verginelli, F., Di Giulio, M., Baffoni, M., et al. (2012). Helicobacter pylori biofilm: a protective environment for bacterial recombination. J. Appl. Microbiol. 113, 669-676. doi: 10.1111/j.13652672.2012.05351.x

Grande, R., Di Marcantonio, M. C., Robuffo, I., Pompilio, A., Celia, C., Di Marzio, et al. (2015). Helicobacter pylori ATCC 43629/NCTC 11639 Outer Membrane Vesicles (OMVs) from biofilm and planktonic phase associated with extracellular DNA (eDNA). Front. Microbiol. 6:1369. doi: 10.3389/fmicb.2015. 01369

Grande, R., Nistico, L., Sambanthamoorthy, K., Longwell, M., Iannitelli, A., Cellini, L., et al. (2014). Temporal expression of agrB, cidA, and alsS in the early development of S. aureus UAMS-1 biofilm formation and the structural role of extracellular DNA and carbohydrates. Pathog. Dis. 70, 414-422. doi: 10.1111/ 2049-632X.12158

Grande, R., Puca, V., and Muraro, R. (2020). Antibiotic resistance and bacterial biofilm. Expert Opin. Ther. Pat. 30, 897-900. doi: 10.1080/13543776.2020. 1830060

Grull, M. P., Mulligan, M. E., and Lang, A. S. (2018). Small extracellular particles with big potential for horizontal gene transfer: membrane vesicles and gene transfer agents. FEMS Microbiol. Lett. 365:fny192. doi: 10.1093/femsle/fny192

Hartel, C., Hartz, A., Bahr, L., Gille, C., Gortner, L., Simon, A., et al. (2016). Media stories on NICU outbreaks lead to an increased prescription rate of third-line antibiotics in the community of neonatal care. Infect. Control. Hosp. Epidemiol. 37, 924-930. doi: 10.1017/ice.2016.95

Innocenti, A., Scozzafava, A., and Supuran, C. T. (2010). Carbonic anhydrase inhibitors. inhibition of transmembrane isoforms IX, XII, and XIV with less investigated anions including trithiocarbonate and dithiocarbamate. Bioorg. Med. Chem. Lett. 20, 1548-1550. doi: 10.1016/j.bmcl.2010.01.081

Jensen, E. L., Clement, R., Kosta, A., Maberly, S. C., and Gontero, B. (2019). A new widespread subclass of carbonic anhydrase in marine phytoplankton. ISME J. 13, 2094-2106.

Kaur, J., Cao, X., Abutaleb, N. S., Elkashif, A., Graboski, A. L., Krabill, A. D., et al. (2020). Optimization of acetazolamide-based scaffold as potent inhibitors of vancomycin-resistant enterococcus. J. Med. Chem. 63, 9540-9562. doi: 10.1021/ acs.jmedchem.0c00734

Kim, J. H., Lee, J., Park, J., and Gho, Y. S. (2015). Gram-negative and grampositive bacterial extracellular vesicles. Semin. Cell. Dev. Biol. 40, 97-104. doi: 10.1016/j.semcdb.2015.02.006

Kohler, S., Ouahrani-Bettache, S., and Winum, J. Y. (2017). Brucella suis carbonic anhydrases and their inhibitors: towards alternative antibiotics? J. Enzyme Inhib. Med. Chem. 32, 683-687. doi: 10.1080/14756366.2017.1295451

Komiya, T., and Huang, C. H. (2018). Updates in the clinical development of epacadostat and other indoleamine 2,3-dioxygenase 1 inhibitors (IDO1) for human cancers. Front. Oncol. 8:423. doi: 10.3389/fonc.2018.00423

Kusian, B., Sultemeyer, D., and Bowien, B. (2002). Carbonic anhydrase is essential for growth of Ralstonia eutropha at ambient $\mathrm{CO}(2)$ concentrations. J. Bacteriol. 184, 5018-5026. doi: 10.1128/JB.184.18.5018-5026.2002 
Littman, J., and Halil, R. (2016). Potential effects of rational prescribing on national health care spending: more than half a billion dollars in annual savings. Can. Fam. Physician 62, 235-244.

Liu, Y., Defourny, K. A. Y., Smid, E. J., and Abee, T. (2018). Gram-positive bacterial extracellular vesicles and their impact on health and disease. Front. Microbiol. 9:1502. doi: 10.3389/fmicb.2018.01502

Llorca, L., Perez-Perez, G., Urruzuno, P., Martinez, M. J., Iizumi, T., Gao, Z., et al. (2017). Characterization of the gastric microbiota in a pediatric population according to Helicobacter pylori status. Pediatr. Infect. Dis. J. 36, 173-178. doi: 10.1097/INF.0000000000001383

Lomelino, C. L., Mahon, B. P., McKenna, R., Carta, F., and Supuran, C. T. (2016a). Kinetic and X-ray crystallographic investigations on carbonic anhydrase isoforms I, II, IX and XII of a thioureido analog of SLC-0111. Bioorg. Med. Chem. 24, 976-981. doi: 10.1016/j.bmc.2016.01.019

Lomelino, C. L., Supuran, C. T., and McKenna, R. (2016b). Non-classical inhibition of carbonic anhydrase. Int. J. Mol. Sci. 17:1150.

Lotlikar, S. R., Kayastha, B. B., Vullo, D., Khanam, S. S., Braga Reygan, E., Murray, A. B., et al. (2019). Pseudomonas aeruginosa $\beta$-carbonic anhydrase, psCA1, is required for calcium deposition and contributes to virulence. Cell Calcium 84:102080.

Maccelli, A., Carradori, S., Puca, V., Sisto, F., Lanuti, P., Crestoni, M. E., et al. (2020). Correlation between the antimicrobial activity and metabolic profiles of cell free supernatants and membrane vesicles produced by Lactobacillus reuteri DSM 17938. Microorganisms 8:E1653.

Manchado, E., Huang, C. H., Tasdemir, N., Tschaharganeh, D. F., Wilkinson, J. E., and Lowe, S. W. (2016). A pipeline for drug target identification and validation. Cold Spring Harb. Symp. Quant. Biol. 81, 257-267.

Manfredo Vieira, S., Hiltensperger, M., Kumar, V., Zegarra-Ruiz, D., Dehner, C., Khan, N., et al. (2018). Translocation of a gut pathobiont drives autoimmunity in mice and humans. Science 359, 1156-1161.

Maresca, A., Carta, F., Vullo, D., and Supuran, C. T. (2013). Dithiocarbamates strongly inhibit the beta-class carbonic anhydrases from Mycobacterium tuberculosis. J. Enzyme Inhib. Med. Chem. 28, 407-411.

Martin, R., Miquel, S., Ulmer, J., Kechaou, N., Langella, P., and BermudezHumaran, L. G. (2013). Role of commensal and probiotic bacteria in human health: a focus on inflammatory bowel disease. Microb. Cell Fact. 12:71.

McKenna, R., and Supuran, C. T. (2014). Carbonic anhydrase inhibitors drug design. Subcell. Biochem. 75, 291-323.

Merlin, C., Masters, M., McAteer, S., and Coulson, A. (2003). Why is carbonic anhydrase essential to Escherichia coli? J. Bacteriol. 185, 6415-6424. doi: 10. 1128/JB.185.21.6415-6424.2003

Modak, J. K., Liu, Y. C., Machuca, M. A., Supuran, C. T., and Roujeinikova, A. (2015). Structural basis for the iinhibition of Helicobacter pylori alpha-carbonic anhydrase by sulfonamides. PLoS One 10:e0127149. doi: 10.1371/journal.pone. 0127149

Modak, J. K., Liu, Y. C., Supuran, C. T., and Roujeinikova, A. (2016). Structureactivity relationship for sulfonamide inhibition of Helicobacter pylori alphacarbonic anhydrase. J. Med. Chem. 59, 11098-11109. doi: 10.1021/acs. jmedchem.6b01333

Modak, J. K., Tikhomirova, A., Gorrell, R. J., Rahman, M. M., Kotsanas, D., Korman, T. M., et al. (2019). Anti-Helicobacter pylori activity of ethoxzolamide. J. Enzyme Inhib. Med. Chem. 34, 1660-1667. doi: 10.1080/14756366.2019. 1663416

Molchanova, N., Hansen, P. R., and Franzyk, H. (2017). Advances in development of antimicrobial peptidomimetics as potential drugs. Molecules 22:1430. doi: 10.3390/molecules22091430

Monti, S. M., Maresca, A., Viparelli, F., Carta, F., De Simone, G., Muhlschlegel, F. A., et al. (2012). Dithiocarbamates are strong inhibitors of the beta-class fungal carbonic anhydrases from Cryptococcus neoformans, Candida albicans and Candida glabrata. Bioorg. Med. Chem. Lett. 22, 859-862. doi: 10.1016/j. bmcl.2011.12.033

Morishita, S., Nishimori, I., Minakuchi, T., Onishi, S., Takeuchi, H., Sugiura, T., et al. (2008). Cloning, polymorphism, and inhibition of beta-carbonic anhydrase of Helicobacter pylori. J. Gastroenterol. 43, 849-857. doi: 10.1007/ s00535-008-2240-3

Nguyen, K., Dersnah, G. D., and Ahlawat, R. (2020). Famotidine. 2020 Jul 10. in: StatPearls. Treasure Island, FL: StatPearls Publishing.

Nishimori, I., Minakuchi, T., Kohsaki, T., Onishi, S., Takeuchi, H., Vullo, D., et al. (2007). Carbonic anhydrase inhibitors: the beta-carbonic anhydrase from
Helicobacter pylori is a new target for sulfonamide and sulfamate inhibitors. Bioorg. Med. Chem. Lett. 17, 3585-3594. doi: 10.1016/j.bmcl.2007.04.063

Nishimori, I., Minakuchi, T., Maresca, A., Carta, F., Scozzafava, A., and Supuran, C. T. (2010). The beta-carbonic anhydrases from Mycobacterium tuberculosis as drug targets. Curr. Pharm. Des. 16, 3300-3309. doi: 10.2174/ 138161210793429814

Nishimori, I., Minakuchi, T., Vullo, D., Scozzafava, A., and Supuran, C. T. (2011). Inhibition studies of the beta-carbonic anhydrases from the bacterial pathogen Salmonella enterica serovar Typhimurium with sulfonamides and sulfamates. Bioorg. Med. Chem. 19, 5023-5030. doi: 10.1016/j.bmc.2011.06.038

Nishimori, I., Onishi, S., Takeuchi, H., and Supuran, C. T. (2008). The alpha and beta classes carbonic anhydrases from Helicobacter pylori as novel drug targets. Curr. Pharm. Des. 14, 622-630. doi: 10.2174/138161208783877875

Nishimori, I., Vullo, D., Minakuchi, T., Morimoto, K., Onishi, S., Scozzafava, A., et al. (2006). Carbonic anhydrase inhibitors: cloning and sulfonamide inhibition studies of a carboxyterminal truncated alpha-carbonic anhydrase from Helicobacter pylori. Bioorg. Med. Chem. Lett. 16, 2182-2188. doi: 10.1016/ j.bmcl.2006.01.044

Nishimori, I., Vullo, D., Minakuchi, T., Scozzafava, A., Capasso, C., and Supuran, C. T. (2014). Sulfonamide inhibition studies of two beta-carbonic anhydrases from the bacterial pathogen Legionella pneumophila. Bioorg. Med. Chem. 22, 2939-2946. doi: 10.1016/j.bmc.2014.04.006

Noto, J. M., and Peak, R. M.., Jr. (2012). The Helicobacter pylori cag pathogenicity island. Methods Mol. Biol. 921, 41-50. doi: 10.1007/978-1-62703-005-2_7

Otten, H. (1986). Domagk and the development of the sulphonamides. J. Antimicrob. Chemother. 17, 689-696. doi: 10.1093/jac/17.6.689

Ozbey, G., Sproston, E., and Hanafiah, A. (2020). Helicobacter pylori infection and gastric microbiota. Euroasian J. Hepatogastroenterol. 10, 36-41. doi: 10.5005/ jp-journals-10018-1310

Ozensoy Guler, O., Capasso, C., and Supuran, C. T. (2016). A magnificent enzyme superfamily: carbonic anhydrases, their purification and characterization. J. Enzyme Inhib. Med. Chem. 31, 689-694. doi: 10.3109/14756366.2015.1059333

Parsek, M. R., and Singh, P. K. (2003). Bacterial biofilms: an emerging link to disease pathogenesis. Annu. Rev. Microbiol. 57, 677-701.

Rahman, M. M., Tikhomirova, A., Modak, J. K., Hutton, M. L., Supuran, C. T., and Roujeinikova, A. (2020). Antibacterial activity of ethoxzolamide against Helicobacter pylori strains SS1 and 26695. Gut Pathog. 12:20.

Roe, M. T., and Pillai, S. D. (2003). Monitoring and identifying antibiotic resistance mechanisms in bacteria. Poult. Sci. 82, 622-626.

Rollenhagen, C., and Bumann, D. (2006). Salmonella enterica highly expressed genes are disease specific. Infect. Immun. 74, 1649-1660.

Ronci, M., Del Prete, S., Puca, V., Carradori, S., Carginale, V., Muraro, R., et al. (2019). Identification and characterization of the alpha-CA in the outer membrane vesicles produced by Helicobacter pylori. J. Enzyme Inhib. Med. Chem. 34, 189-195.

Rossi, C., and Sternon, J. (2001). Third and fourth generation fluoroquinolones. Rev. Med. Brux. 22, 443-456.

Scozzafava, A., Mastrolorenzo, A., and Supuran, C. T. (2000). Arylsulfonyl-N,Ndiethyl-dithiocarbamates: a novel class of antitumor agents. Bioorg. Med. Chem. Lett. 10, 1887-1891. doi: 10.1016/S0960-894X(00)00375-9

Scozzafava, A., Mastrolorenzo, A., and Supuran, C. T. (2001). Arylsulfonyl-N,Ndialkyl-dithiocarbamates as tumor cell growth inhibitors: novel agents targeting beta-tubulin? J. Enzyme Inhib. 16, 55-63.

Selzer, P. M., Brutsche, S., Wiesner, P., Schmid, P., and Mullner, H. (2000). Targetbased drug discovery for the development of novel antiinfectives. Int. J. Med. Microbiol. 290, 191-201. doi: 10.1016/S1438-4221(00)80090-9

Shahidzadeh, R., Opekun, A., Shiotani, A., and Graham, D. Y. (2005). Effect of the carbonic anhydrase inhibitor, acetazolamide, on Helicobacter pylori infection in vivo: a pilot study. Helicobacter 10, 136-138. doi: 10.1111/j.1523-5378.2005. 00306.x

Singh, S., and Supuran, C. T. (2014). 3D-QSAR CoMFA studies on sulfonamide inhibitors of the Rv3588c beta-carbonic anhydrase from Mycobacterium tuberculosis and design of not yet synthesized new molecules. J. Enzyme Inhib. Med. Chem. 29, 449-455. doi: 10.3109/14756366.2013.800059

Sosa, E. J., Burguener, G., Lanzarotti, E., Defelipe, L., Radusky, L., Pardo, A. M., et al. (2018). Target-Pathogen: a structural bioinformatic approach to prioritize drug targets in pathogens. Nucleic Acids Res. 46, D413-D418.

Supuran, C. T. (2008). Carbonic anhydrases: novel therapeutic applications for inhibitors and activators. Nat. Rev. Drug Discov. 7, 168-181. 
Supuran, C. T. (2012). Structure-based drug discovery of carbonic anhydrase inhibitors. J. Enzyme Inhib. Med. Chem. 27, 759-772. doi: 10.3109/14756366. 2012.672983

Supuran, C. T. (2016a). Carbonic anhydrase inhibition and the management of neuropathic pain. Expert Rev. Neurother. 16, 961-968.

Supuran, C. T. (2016b). Drug interaction considerations in the therapeutic use of carbonic anhydrase inhibitors. Expert Opin. Drug Metab. Toxicol. 12, 423-431.

Supuran, C. T. (2016c). How many carbonic anhydrase inhibition mechanisms exist? J. Enzyme Inhib. Med. Chem. 31, 345-360.

Supuran, C. T. (2016d). Legionella pneumophila carbonic anhydrases: underexplored antibacterial drug targets. Pathogens 5:44.

Supuran, C. T. (2016e). Structure and function of carbonic anhydrases. Biochem. J. 473, 2023-2032.

Supuran, C. T. (2017a). Advances in structure-based drug discovery of carbonic anhydrase inhibitors. Expert Opin. Drug Discov. 12, 61-88. doi: 10.1080/ 17460441.2017.1253677

Supuran, C. T. (2017b). Special issue: sulfonamides. Molecules 22:1642. doi: 10. 3390/molecules 22101642

Supuran, C. T., and Capasso, C. (2015). The eta-class carbonic anhydrases as drug targets for antimalarial agents. Expert Opin. Ther. Targets 19, 551-563. doi: $10.1517 / 14728222.2014 .991312$

Supuran, C. T., and Capasso, C. (2016). New light on bacterial carbonic anhydrases phylogeny based on the analysis of signal peptide sequences. J. Enzyme Inhib. Med. Chem. 31, 1254-1260. doi: 10.1080/14756366.2016.1201479

Supuran, C. T., and Capasso, C. (2017). An overview of the bacterial carbonic anhydrases. Metabolites 7:56. doi: 10.3390/metabo7040056

Supuran, C. T., and Capasso, C. (2018). Biomedical applications of prokaryotic carbonic anhydrases. Expert Opin. Ther. Pat. 28, 745-754. doi: 10.1080/ 13543776.2018.1497161

Supuran, C. T., and Capasso, C. (2020). Antibacterial carbonic anhydrase inhibitors: an update on the recent literature. Expert Opin. Ther. Pat. 30, 963-982. doi: 10.1080/13543776.2020.1811853

Tarsia, C., Danielli, A., Florini, F., Cinelli, P., Ciurli, S., and Zambelli, B. (2018). Targeting Helicobacter pylori urease activity and maturation: in-cell highthroughput approach for drug discovery. Biochim. Biophys. Acta Gen. Subj. 1862, 2245-2253. doi: 10.1016/j.bbagen.2018.07.020

Ueda, K., Nishida, H., and Beppu, T. (2012). Dispensabilities of carbonic anhydrase in proteobacteria. Int. J. Evol. Biol. 2012:324549. doi: 10.1155/2012/324549

Vullo, D., De Luca, V., Del Prete, S., Carginale, V., Scozzafava, A., Capasso, C., et al. (2015a). Sulfonamide inhibition studies of the gamma-carbonic anhydrase from the Antarctic bacterium Pseudoalteromonas haloplanktis. Bioorg. Med. Chem. Lett. 25, 3550-3555. doi: 10.1016/j.bmcl.2015.06.079

Vullo, D., De Luca, V., Del Prete, S., Carginale, V., Scozzafava, A., Capasso, C., et al. (2015b). Sulfonamide inhibition studies of the gamma-carbonic anhydrase from the Antarctic cyanobacterium Nostoc commune. Bioorg. Med. Chem. 23, 1728-1734. doi: 10.1016/j.bmc.2015.02.045

Vullo, D., Del Prete, S., Fisher, G. M., Andrews, K. T., Poulsen, S. A., Capasso, C., et al. (2015c). Sulfonamide inhibition studies of the eta-class carbonic anhydrase from the malaria pathogen Plasmodium falciparum. Bioorg. Med. Chem. 23, $526-531$.
Vullo, D., Nishimori, I., Minakuchi, T., Scozzafava, A., and Supuran, C. T. (2011). Inhibition studies with anions and small molecules of two novel betacarbonic anhydrases from the bacterial pathogen Salmonella enterica serovar Typhimurium. Bioorg. Med. Chem. Lett. 21, 3591-3595. doi: 10.1016/j.bmcl. 2011.04.105

Vullo, D., Sai Kumar, R. S., Scozzafava, A., Capasso, C., Ferry, J. G., and Supuran, C. T. (2013). Anion inhibition studies of a beta-carbonic anhydrase from Clostridium perfringens. Bioorg. Med. Chem. Lett. 23, 6706-6710. doi: 10.1016/ j.bmcl.2013.10.037

Walsh, T. R. (2005). The emergence and implications of metallo-beta-lactamases in Gram-negative bacteria. Clin. Microbiol. Infect. 11(Suppl. 6), 2-9. doi: 10.1111/ j.1469-0691.2005.01264.x

Wang, J. D., and Levin, P. A. (2009). Metabolism, cell growth and the bacterial cell cycle. Nat. Rev. Microbiol. 7, 822-827. doi: 10.1038/nrmicro2202

Warren, J. R. (2000). Gastric pathology associated with Helicobacter pylori. Gastroenterol. Clin. North Am. 29, 705-751. doi: 10.1016/S0889-8553(05) 70139-4

Warren, J. R. (2006). Helicobacter: the ease and difficulty of a new discovery (Nobel lecture). ChemMedChem 1, 672-685.

Watford, S., and Warrington, S. J. (2020). Bacterial DNA Mutations. in: StatPearls. Treasure Island, FL: StatPearls Publishing.

Ye, S. J., Fang, P. C., Mao, G. G., Li, C. L., Qiu, X., and Chen, H. X. (2003). Purification and relationship with gastric disease of a 130 $\mathrm{kDa}$ (CagA) protein of Helicobacter pylori. J. Zhejiang Univ. Sci. 4, $232-235$.

Yonezawa, H., Osaki, T., and Kamiya, S. (2015). Biofilm formation by Helicobacter pylori and its involvement for antibiotic resistance. Biomed. Res. Int. 2015:914791. doi: 10.1631/jzus.2003.0232

Zagato, E., Pozzi, C., Bertocchi, A., Schioppa, T., Saccheri, F., Guglietta, S., et al. (2020). Endogenous murine microbiota member Faecalibaculum rodentium and its human homologue protect from intestinal tumour growth. Nat. Microbiol. 5, 511-524. doi: 10.1155/2015/914791

Zhu, J. Y., Zhai, H. H., and Li, P. (2020). Diagnosis and follow-up of chronic atrophic gastritis. Chin. J. Intern. Med. 59, 71-74. doi: 10.1038/s41564-0190649-5

Conflict of Interest: RG and SC have a scientific collaboration with BioGaia AB (Stockholm, Sweden).

The remaining authors declare that the research was conducted in the absence of any commercial or financial relationships that could be construed as a potential conflict of interest.

Copyright (c) 2021 Campestre, De Luca, Carradori, Grande, Carginale, Scaloni, Supuran and Capasso. This is an open-access article distributed under the terms of the Creative Commons Attribution License (CC BY). The use, distribution or reproduction in other forums is permitted, provided the original author(s) and the copyright owner(s) are credited and that the original publication in this journal is cited, in accordance with accepted academic practice. No use, distribution or reproduction is permitted which does not comply with these terms. 